\title{
High-level expression of a novel thermostable and mannose-tolerant $\beta$-mannosidase from Thermotoga thermarum DSM 5069 in Escherichia coli
}

\author{
Hao Shi ${ }^{1,2}$, Yingjuan Huang ${ }^{1,2}$, Yu Zhang ${ }^{1,2}$, Wenqian $\mathrm{Li}^{1,2}$, Xun $\mathrm{Li}^{1,2}$ and Fei Wang ${ }^{1,2^{*}}$
}

\begin{abstract}
Background: Mannan is one of the primary polysaccharides in hemicellulose and is widely distributed in plants. $\beta$-Mannosidase is an important constituent of the mannan-degrading enzyme system and it plays an important role in many industrial applications, such as food, feed and pulp/paper industries as well as the production of second generation bio-fuel. Therefore, the mannose-tolerant $\beta$-mannosidase with high catalytic efficiency for bioconversion of mannan has a great potential in the fields as above.

Results: A $\beta$-mannosidase gene (Tth man5) of 1,827 bp was cloned from the extremely thermophilic bacterium Thermotoga thermarum DSM 5069 that encodes a protein containing 608 amino acid residues, and was overexpressed in Escherichia coli BL21 (DE3). The results of phylogenetic analysis, amino acid alignment and biochemical properties indicate that the Tth Man5 is a novel $\beta$-mannosidase of glycoside hydrolase family 5 . The optimal activity of the Tth Man5 $\beta$-mannosidase was obtained at pH 5.5 and $85^{\circ} \mathrm{C}$ and was stable over a pH range of 5.0 to 8.5 and exhibited $2 \mathrm{~h}$ half-life at $90^{\circ} \mathrm{C}$. The kinetic parameters $K_{m}$ and $V_{\max }$ values for $p$-nitrophenyl- $\beta$-D-mannopyranoside and 1,4- $\beta$-D-mannan were $4.36 \pm 0.5 \mathrm{mM}$ and $227.27 \pm 1.59 \mu \mathrm{mol} \mathrm{min}{ }^{-1} \mathrm{mg}^{-1}, 58.34 \pm 1.75 \mathrm{mg} \mathrm{mL}^{-1}$ and $285.71 \pm 10.86$ $\mu \mathrm{mol} \mathrm{min} \mathrm{mg}^{-1}$, respectively. The $k_{\text {cat }} / K_{m}$ values for $p$-nitrophenyl- $\beta$-D-mannopyranoside and 1,4- $\beta$-D-mannan were $441.35 \pm 0.04 \mathrm{mM}^{-1} \mathrm{~s}^{-1}$ and $41.47 \pm 1.58 \mathrm{~s}^{-1} \mathrm{mg}^{-1} \mathrm{~mL}$, respectively. It displayed high tolerance to mannose, with a $K_{i}$ value of approximately $900 \mathrm{mM}$.
\end{abstract}

Conclusions: This work provides a novel and useful $\beta$-mannosidase with high mannose tolerance, thermostability and catalytic efficiency, and these characteristics constitute a powerful tool for improving the enzymatic conversion of mannan through synergetic action with other mannan-degrading enzymes.

Keywords: Thermotoga thermarum, $\beta$-mannosidase, Mannose-tolerant, Mannan, Thermostability, Mannooligosaccharides

\section{Background}

Mannans are complex polysaccharides representing one of the major components of hemicellulose, consisting of four types: linear mannan, glucomannan, galactomannan, and galactoglucomanan [1]. Each of these polysaccharides has a $\beta$-1,4-linked backbone units including mannose or a combination of glucose and mannose residues, with the presence of $\alpha$-1,6-linked side-chain substitutions [2]. It

\footnotetext{
* Correspondence: hgwf@njfu.edu.cn

'College of Chemical Engineering, Nanjing Forestry University, Nanjing 210037, China

${ }^{2}$ Jiangsu Key Lab of Biomass-Based Green Fuels and Chemicals, Nanjing 210037, China
}

was reported that the hydrolysis of these polysaccharides requires several mannan-degrading enzymes, primarily including $\beta$-mannanase (EC 3.2.178), $\beta$-mannosidase (EC 3.2.1.25) and $\beta$-glucosidase (EC 3.2.1.21). Other enzymes such as $\alpha$-galactosidase and mannan esterase are required to remove $\alpha$-galactosyl and $\mathrm{O}$-acetyl side-chain substituent. Among these enzymes, two types of mannandegrading enzymes are necessary [3]. One endotype, $\beta$-mannanase, is responsible for the cleavage of $\beta-1,4$ linked mannose residues backbone randomly to generate mannooligosaccharides. Another exotype, $\beta$-mannosidase, hydrlyses the nonreducing end of mannooligosaccharides 
to release mannoses [2]. It is known that $\beta$-mannosidase is produced from plants, bacterial, fungi, invertebrates as well as some mammalian species [4,5]. Based on amino acid similarity and multi-domains, $\beta$-mannosidases have been mainly classified into glycoside hydrolase family (GHF) 1 , 2 and 5 (http://www.cazy.org/). These $\beta$-mannosidases from different GHFs possess considerable industrial applications in many fields, such as food, feed and pulp/paper industries [6]. In addition, $\beta$-mannosidases have important role in saccharification of hemicellulose for fuel and other chemicals production. In human, lack of $\beta$-mannosidase can lead to $\beta$-mannosidosis $[7,8]$.

During the last two decades, thermostable enzymes from thermophilic or hyperthermophilic microorganisms have become the hotspots of researches in many fields [9]. The amino acid sequences of $\beta$-mannosidases are abundantly available on the constantly updating databases. However, only a few $\beta$-mannosidases especially from hyperthermophile have been cloned, purified and characterized $[3,5,10]$. It was found that the known hyperthermophilic $\beta$-mannosidases from Pyrococcus furiosus, Thermotoga maritima, and Thermotoga neapolitana belonged to the GHF1, GHF2, and GHF2, respectively [11-13]. Thermotoga thermarum, isolated from continental solfataric springs at Lac Abbe (Djibouti, Africa), is an anaerobic hyperthermophilic bacteria that grows at $80^{\circ} \mathrm{C}$ [14]. And it has many glycoside hydrolase genes based on the genomic sequence (GenBank accession number: CP002351).

The biotechnology industry is essential in modern societies [15], which is reflected in the production of recombinant enzymes (including $\beta$-mannosidases) and their applications. In this study, we described the cloning, expression and functional characterizations of a novel recombinant $\beta$-mannosidase (Tth Man5) in E. coli.

\section{Results}

Amino acid sequence of Tth Man5 $\beta$-mannosidase

The Tth man5 gene isolated from the T. thermarum genome was 1,824 bp in length coding 608 amino acids and it was predicted as an endo- $\beta$-mannanase (Theth_0949) available at NCBI and CAZy sites (http://www.ncbi.nlm. nih.gov/, http://www.cazy.org/) (Lucas S etal, 2011). As shown in Figure 1, Tth Man5 displayed 33\% identity to $\beta$-mannosidase from Sorangium cellulosum So ce56, 32\% identity to putative $\beta$-mannosidase from Actinosynnema mirum DSM 43827 and 32\% identity to the glycoside hydrolase from Streptomyces flavogriseus ATCC 33331. The results of alignments also revealed that Glu141, Glu237, Glu238, Glu292 and Glu591 were conserved amino acids among these GHF5 $\beta$-mannosidases. According to the CAZy database, two glutamic acids are the acid/base and the nucleophile, respectively. Against the similar catalytic domain of GHF5 endoglucanase (EXPDB
No: 1TVP_A) from Pseudoalteromonas haloplanktis, it was presumed that active amino acids of Tth Man5 $\beta$ mannosidase were Glu141 and Glu238 [16].

\section{Over-expression and purification of Tth Man5 $\beta$-mannosidase}

When using native gene from $T$. thermarum for expression, the protein production was very difficult to detected (data not shown). Thus, in order to increase the expression level of Tth Man $5 \beta$-mannosidase in Escherichia coli, rare codons were replaced by optimal codons without change of amino acid sequence (data not shown). The mature protein without the signal peptide, allowing the insertion of a $\mathrm{His}_{6}$-tag at the C-terminus, was successfully expressed in E. coli BL21 (DE3), after induction with IPTG for $5 \mathrm{~h}$ at $37^{\circ} \mathrm{C}$. The recombinant protein in the cell-free extract was purified by a heat treatment followed by a nickel affinity column (Table 1). Finally, the purified recombinant enzyme displayed a single band on SDSPAGE with an estimated molecular weight (MW) of 70 $\mathrm{kDa}$ (Figure 2), which was consistent with the predicted MW of monomer (71, $725 \mathrm{Da})$. Size exclusion chromatography was also carried out using the AKTAFPLC ${ }^{\mathrm{rm}}$ system to compute the oligomerization state of the target protein. It was deduced that the native protein formed 7-mer in solution with a calculated MW $508,019 \mathrm{Da}$ according to the calibration curve of the gel filtration column.

\section{Biochemical characteristics of Tth Man5 $\beta$-mannosidase}

The enzymatic properties of purified recombinant $T$ th Man5 $\beta$-mannosidase were determined and summarized in Tables 2, 3 and 4. Substrate specificity was assayed with different substrates and Tth Man $5 \beta$-mannosidase was found to be active to $p$-nitrophenyl- $\beta$-D-mannopyranoside $(p$ NPM $)$ and 1,4- $\beta-D-m a n n a n$. However, no activity was detected towards konjaku powder, guar galactomannan and galactan (Table 2). These results indicated that the enzyme showed only exo-enzyme activity, which is not consistent with the prediction on its function at NCBI and CAZy.

The recombinant Tth Man5 $\beta$-mannosidase has a $\mathrm{pH}$ optimum of 5.5 as shown in Figure 3a. The enzyme was relatively stable at a $\mathrm{pH}$ range of 5.0 to 8.5 and most stable at pH 5.5 (Figure 3b). More than $70 \%$ of the initial enzyme activity remained at this range. The enzyme was most active at $85^{\circ} \mathrm{C}$, and it retained approximately $50 \%$ of the maximum activity at $95^{\circ} \mathrm{C}$ (Figure 3c). The thermostability data showed that it remained above $56 \%$ of its initial activity after $2 \mathrm{~h}$ of pre-incubation at temperature ranging from $75^{\circ} \mathrm{C}$ to $90^{\circ} \mathrm{C}$ (Figure 3d).

The effects of metal ions and chemical reagents on the enzyme activity are shown in Table 3. In various assays, the enzyme activity was apparently stimulated by $1 \mathrm{mM}$ $\mathrm{Mn}^{2+}, \mathrm{Co}^{2+}$ and ethylene diamine tetraacetic acid (EDTA). 


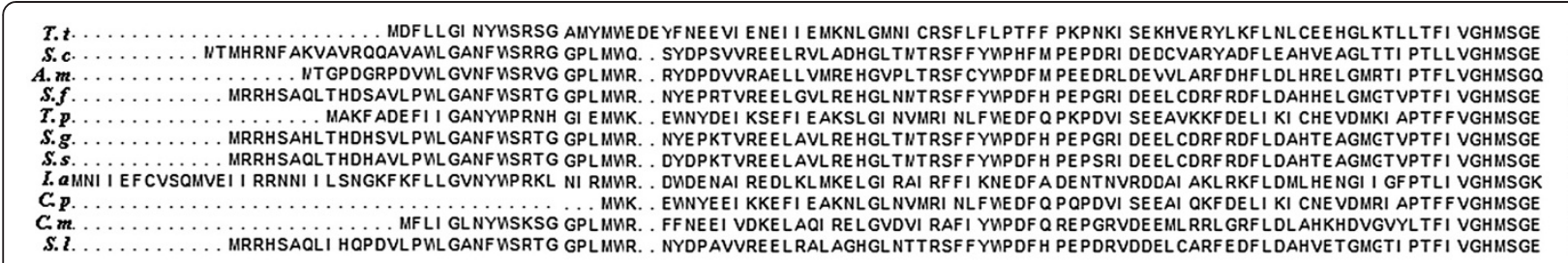
T. $t$ NF DPPF RNCRDL YMDE FML QQQCFFVKSI VEKVRSSPAVYGYI LSNE MPLYGG.

TGEPEKVLNUVKKLVEVI KSVDPTRPVGTGDGCUNVFG. . GENGFNLREI SKI VDYLGPH S. $c$ NWDPAURRGRDL YGDVWMVARQAWF AE QMARRF AGHRAVT GULVSNEMPI YG. . . . ERERSI RE NUTSUASL VVQALRAGGASQPI SI GDGAUGI EVTGNDNGF SVRDL GALVDFLGPH A.m NWDP PURRGRDVF GDE SF VARQRUYVRE LSARUKDHPAVAGULL GNEI PL YADERSRGVGTLDADVUTAWADALI GE VRAAGARQPVSVGDGAUGVEVTGL DNGF RVRDLAPL VDF HGPH S.f NWDPAWRGDRDL YEDVWL VGRQAUFVSQUTRRF KDHPAVT GULI TNE MPGYGR. . I YQVDPPSSDVUTAWAQF MCDAVRAAGGTQPVSLGDGAUGI EVTGRDNGF SLRETAE YVDF VGPH

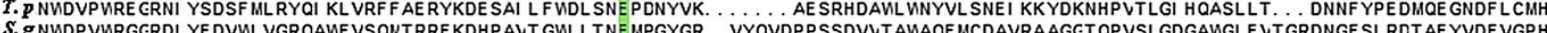

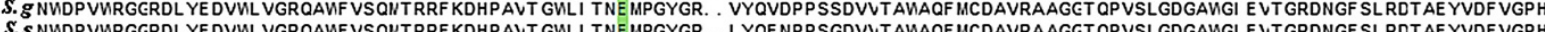
S. $S$ NWDPVWRGGRDL YE DVWL VGRQAWFVSQIITRRF KDHPAVT GULI TNE MPGYGR. I. a NUVI PVTSFDDLYKSN. SI EKTMRFI EHI VKTFKDHPAI GGUI LSNELSLVKK. C.P NUDVPURE GKNI YSDSYMLRYQL KL VRFFAERYKDQDAI LFUDLSNEPDNYVK.
C. $m$ NUDPQURGGRDFFE. . LRNEVKVLI ETI VSRFRGHPAI RGWI LSNELPI YAT.

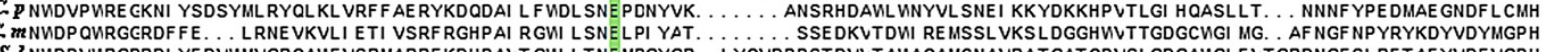
ASRRE ALALLRAYSKTVKSI DNKHI I SSGDVPDSYMO ...... ETPNVRELVDYI GPH S. I NWDPVURGDRDL YEDVMMVGRQAWFVSRMARRF KDHPAVT GULI TNEMPGYGR. II YQVDPPSTDVUTAWAQAMCNAVRATGATQPVSLGDGAVGI EVTGRDNGF SLRETAEYVDFVGPH

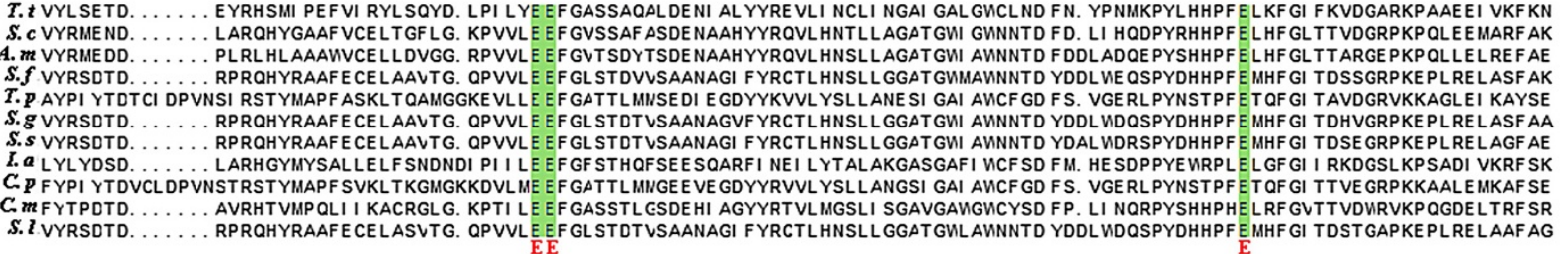
DAALI VPSYLE GAFPFTEAEDR SYLF. A. $m$ VLRRTDFACLRRPDA. s. $f$ VLERVDF PRCRRTDA. . . DAALVVPSFLERGYPYSRPADR PLI F . . T. $\boldsymbol{p}$ F MNRI EYKDLKHKKC. . DAAI I I PDKYYSALFVGNDYTP ERNF . S. $g$ VLKRVDF ARCRRTDA. . . DAAL VVPAFLERGYPYSRPADR PLI F. . . $s . s$ VLERVDFAHCRRTDA. . . DAALVVPAFLERGYPYSRPADR PLI F. I. a DLERLEDMGI NERYERYI DTSI I VPYYLF KDYEFI UYKNALGF UG $C P$ FLREVEYEKLRPKES. . . DAAI I I PDKYYEALFVGKDYTP ERNF. C. $m$ LI STLG. . DVE PVED. ... PVAVLF PSYVYYSYPFTSRDDARKI S.

KHLL QATVL CAKAGFV. TILLRQAYI AAKEADLP. EHGRQAYAAARE ADLP. TSLHQGYVAARGADLP. RILLNSFI LAKEAGI D. TSLHQGYVAARGADLP. QPI I ASYI I SKAAGLCT. RI LLNSFI LAKQAGLD. TSLHQGYUTARAADLP.
VDLVE EENYKRUKSYKLI I LPSERK. . YLATTUENLHKYVQAGGN VGLTRERD. GI AEDCRLYLLPSAKQ. . LTAPTYHLLERLSSAGAV VGVAR EVD. GVPDDCALYLLPSAKQ. . LLAPTURELLLRASE GAV VAFAR EAD. GLPDNASLYLLPSTRQ. . LTTRTTRRDLERRARE GAT VELAR ADG. DFSKYKIMLI LPSAYRKGHLNYDQUVKI MDFVKNGGT VAFAR EAD. GLPDDAALYLLPSTRQ. . LTTRTRRALERRARE GAT VALTR EAD. GLAEDAAL YLLPSTRQ. . LTTRTRRALERRARE GAT SMI YE LDI ERKARDKKMLI MPSTI T. . ALASTURKLL GYVEDGGN VDLI R PED. DF KKYKLLI VPSAYRKGHLTYSQULKVMEFVKEGGT GVI I EE GRS. KI SGDVKVLFLPCALR. . YLACTQEEI RRF VE KGGV
VALTR EAD. GMPGEASLYLLPATRQ. . LTTRTRRELARRAAE GAT

\section{5

T. $t$ LYI SYYUGK. . YDFHQGI USQNLESLI GCKLNLRYGLTSSLPS. . . . . KVKLEYGGLTUKLNVE KCNE UE KSYAPI VSI LETAESI ELGQSDLQLVKNKVGSGKVFFI NFPLEHI LSV S. $c$ VYASYCHGT. . HGSQRGPUYAHLNAMF GVE HQLRYGII DPI EDDRAKLTFE CQF GTI AAGTTLTFF PVSGTEHSRAYLPVR PRGAEVVAVDQRGRPALLRRKI GSGSVVLCTYPI EHFAAA A. $m$ VYASYF HGA. . HKVQRGSUMPDLDGMF GVAKRSRYGL VE PVVE DELRLRVVTGF GGLAVGE ELVF AVGGNE HSRAFLPVD PVEAE VLAVDGRGRPALLRRRVGAGAMVL CAYPLE HMASA S.f VYLSF CSGE. . YPTTRGPUF HDLDGLF GVELQLSYGVAEPI EDDVLEWTFTEDFGSI AAGEVLTF PVAGNEDSRAYLPVV PDGARVVATDAHGRPALLRYETGAGRTVLATYPLEHMAAR T. $P$ LYVSY........ DGI SLE GFDEVFGVK. . TQYSMVPKNET....... VSMHCEELGI DLNYKALKF NKR. ... LI AK PTTGRVI ANDDE NNPAI VVNKYGE GNAI LVTYPI ELYLSY S.g VYLSFCSGE. . HPGTRGPWFDDLDGLF GVELQLSYGVAEPI EDDVLE WTFAEDF GSI AAGE TLVFPVAGNEDSRAYLPVV PTGARVVATDAHGRPALLCHETGE GRTVLATYPLE HMAAR S.s VYLSFCSGE. . HPGTRGPVFDDLDGLF GVELQLSYGVAEPI EDDVLEVTFTEEFGTI KAGETLTFPVAGNEDSRAYLPVV PKGARVVATDAHGRPALLRHDTGQGRTVLATYPLEHMAAR I. $a$ LYVSMVRGVGML KAL HE SPTHL UGELF GVENTLE VGSVGQKYVNQI NI VF AKDF GVMRKGDTI SLNI MEPI YT. . . YKAR AI DADVI AEDSE GRPVI FRVRRGKGNVYLNLLPI EI ALAR

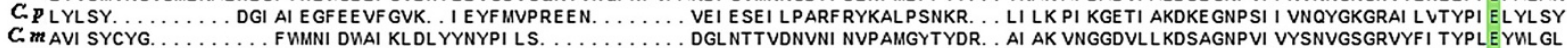
S.l. VYLSF CSGE. . HPVTRGPUF DDLDGLF GVELQLSYGVAEPI EDDVLELTFTEDF GDLRAGE VLRF PVAGNEDSRAYLPVE PRAGRVVAVDAHGRPALVVHETGVGRTVLSTYPLEHMAAR

T.t NEKI NLSDLSHLI YRCI AKQASLN. LCYCDNQRVRVRKI K SG. RKTLYLI QNI AUDKE QVCT. . . . S. $c$ TPRI N. PEFTYKI YDALAELAGVKRPVTVDDPRVAADTLR HRDGRRFVFLVSQADQPLSVKPAA. A. $m$ TPSVN. PELTURL YAALAAE AGVVPE VSVDDPGVL VSVLE HEDGRRF AVL VSQRGE PVSARV S. $f$ TARAN. PEFTHRL YAALAELAGAARPUTVETPYVSADTLVHEDGTRFVVLVSQSGEELTVRP. A . T. $P$ MPDVYKTDRSYLI YKYAKELSGI EYNVKVE SPYI EVKEFD YG. GKTLVLFI NHEDI DI HTKI RI SRKT S. $g$ TARAN. PECTHRLYAALAEVSGAARPVTVDSPYVAADTLVREDGTRYVVLVSQSEAELSVRP. V. S.s TARVN. PECTHRLYAALAEI AGAARPVTVDSPHVAADTLVHEDGRRF VVLVSQSGTELTVRP. S. 1. a SDI VDUSSNI HRL YESI ALDI GI EPLYRSSDPE VEVNI YT GGDSDI VI AVNHGKTKSCTI ASKRSI LEA
$C$ P MPDVYKSNESF KI YQLAKRLAGI VYEVEVDSPYVE VKEFN FE. NRKLI LLI NHENEEVRI GVKL KDKGRF C. $m$ SPKPFE NHDAHLLYNLI LRRE GI G. . ALTPSKUVQVARLK SS. KYSYVAYI NHGUSDVKI NVSG.

S.l TARVN. PDITORLYGALAQLAGVRRPUTVADPHVSADVLVHADGRRFVVLVSOSPDPLVVRP. A.

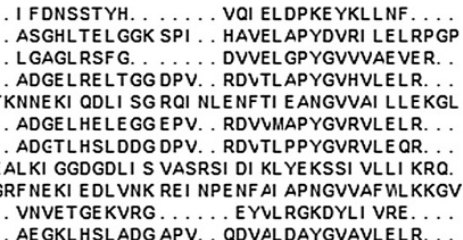

Figure 1 Multi-alignment of Tth Man5 $\beta$-mannosidase with other GHF5 members. Sequence alignment was performed by using Clustal X2.0. Thermotoga thermarum (T. t): GenBank No. AEH51033; Sorangium cellulosum (S. c): GeneBank No. YP_001611298; Actinosynnema mirum (A. m): GenBank No. YP_003101832; Streptomyces flavogriseus (S. f): GenBank No. YP_004925051; Streptomyces globisporus (S. g): GenBank No. ZP_11381673; Streptomyces sp. (S. s): GenBank No. ZP_09180515; Ignisphaera aggregans (I. a): GenBank No. YP_003859038; Carboxydibrachium pacificum (C. p): GenBank No. ZP_05092335; Caldivirga maquilingensis (C. m): GenBank No. YP_001540758; Streptomyces lividans (S. I): GenBank No. ZP_06533254.

However, the enzyme activity was apparently inhibited by $1 \mathrm{mM} \mathrm{Cu}^{2+}$ and $\mathrm{Zn}^{2+}, 0.05 \%$ Tris and $0.1 \%$ SDS. Enzyme kinetic studies in the addition of $p$ NPM and 1,4- $\beta$-D-mannan as the substrate at optimum temperature and $\mathrm{pH}$ allowed the determination of the Michaelis-Menten parameters (Table 4 , data for 1,4- $\beta$-D-mannan was not summarized in this table). The enzyme had an obvious $K_{m}$ of $4.36 \pm 0.5 \mathrm{mM}, V_{\max }$ of $227.27 \pm 1.59 \mu \mathrm{mol} \mathrm{min}{ }^{-1} \mathrm{mg}^{-1}$ and $k_{\text {cat }} / K_{m}$ of $441.35 \pm 0.04 \mathrm{mM}^{-1} \mathrm{~s}^{-1}$ using $p \mathrm{NPM}$ as substrate, while $K_{m}$ of $58.34 \pm 1.75 \mathrm{mg} \mathrm{ml}^{-1}, V_{\max }$ of $285.71 \pm 10.86$ $\mu \mathrm{mol} \mathrm{min} \mathrm{mg}^{-1}$ and $k_{\text {cat }} / K_{m}$ of $41.47 \pm 1.58 \mathrm{~s}^{-1} \mathrm{mg}^{-1} \mathrm{~mL}$ for 1,4- $\beta$-D-mannan. The effect of mannose concentration on the Tth Man5 $\beta$-mannosidase activity was also investigated (shown in Figure 4). Though the enzyme activity was gradually decreased with the increase of mannose concentration, the enzyme could retain $50 \%$ of its initial 
Table 1 Purification of the recombinant Tth Man5 $\beta$-mannosidase

\begin{tabular}{|c|c|c|c|c|c|c|}
\hline Purification step & Total volume $(\mathrm{mL})$ & $\begin{array}{l}\text { Total activity } \\
\left(\mu \mathrm{mol} \mathrm{min}{ }^{-1}\right) \\
\end{array}$ & Total protein $(\mathrm{mg})$ & 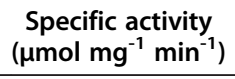 & Recovery (\%) & $\begin{array}{c}\text { Purification } \\
\text { (fold) }\end{array}$ \\
\hline Crude extract $^{a}$ & 10 & 2160 & 135 & 16 & 100 & 1 \\
\hline Heat treatment ${ }^{b}$ & 10 & 1922 & 31 & 62 & 89.0 & 3.9 \\
\hline $\mathrm{Ni}$ affinity chromatography ${ }^{\mathrm{c}}$ & 1 & 1734 & 17 & 102 & 80.3 & 6.4 \\
\hline
\end{tabular}

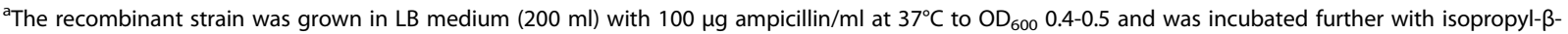
thiogalactopyranoside (IPTG) for $5 \mathrm{~h}$. The cells were harvested by centrifugation at $10,000 \mathrm{~g}$ for $15 \mathrm{~min}$ at $4^{\circ} \mathrm{C}$ and resuspended in $10 \mathrm{ml}$ imidazole buffer (10 mL of $5 \mathrm{mM}$ imidazole, $0.5 \mathrm{mM} \mathrm{NaCl}$, and $20 \mathrm{mM}$ Tris-HCl buffer, $\mathrm{pH}$ 7.9), followed by sonication.

${ }^{\text {b}}$ The cell extracts after sonication were heat treated at $70^{\circ} \mathrm{C}$ for $30 \mathrm{~min}$, and then cooled in an ice bath, centrifuged at $15,000 \mathrm{~g}$ for $20 \mathrm{~min}$ at $4^{\circ} \mathrm{C}$ and the supernatant was kept.

'The obtained supernatants were loaded on to an immobilized metal affinity column (Novagen, USA), and eluted with $0.4 \mathrm{M}$ imidazole, $0.5 \mathrm{M} \mathrm{NaCl}$, and $20 \mathrm{mM}$ Tris-HCl buffer (pH 7.9).

activity at $900 \mathrm{mM}$ of mannose concentration, indicating Tth Man5 $\beta$-mannosidase is a mannose-tolerant $\beta$ mannosidase with a $K_{i}$ of $900 \mathrm{mM}$ mannose.

\section{Hydrolysis of 1,4- $\beta$-D-mannan by the purified Tth Man5 $\beta$-mannosidase}

Tth Man5 $\beta$-mannosidase was capable of degrading not only $p$ NPM but also polymer mannan. The mode of action of Tth Man $5 \beta$-mannosidase was determined by analyzing the products of digestion of 1,4- $\beta$-D-mannan (Figure 5). The end products were almost the mannose

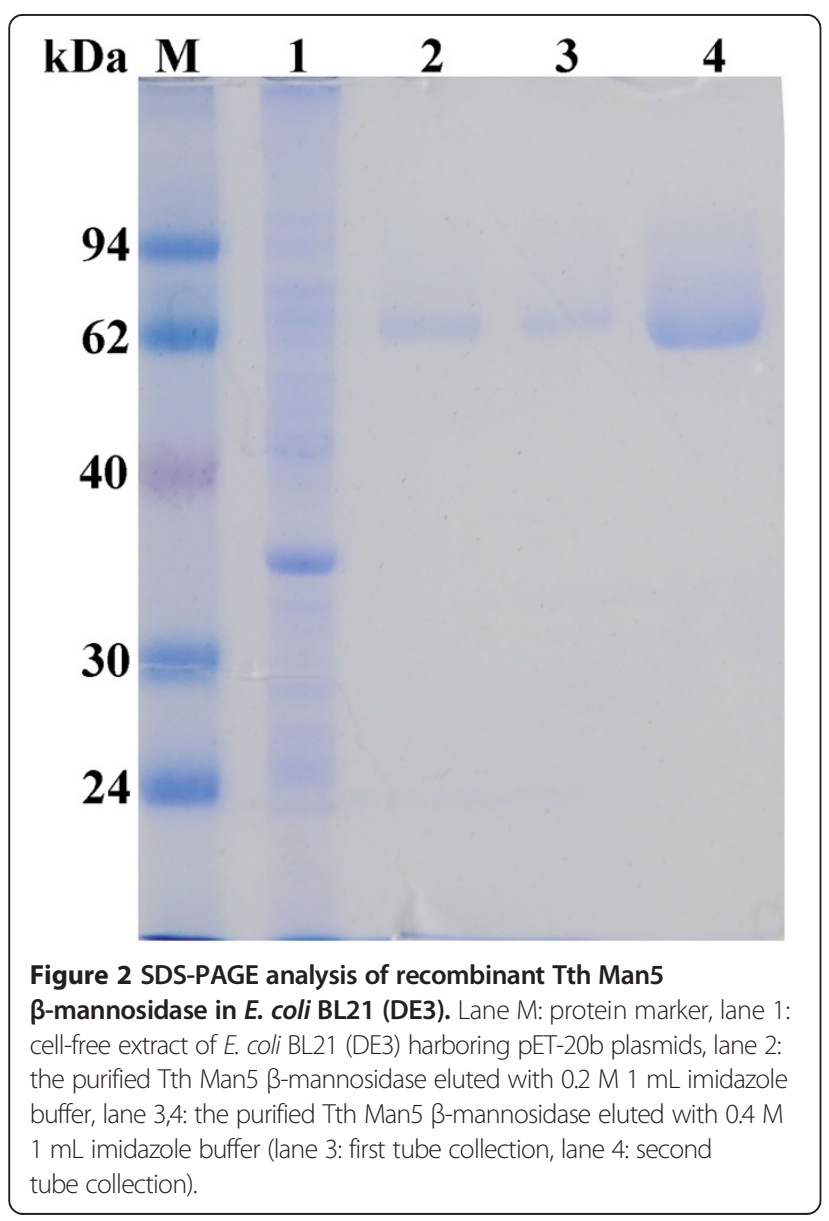

after degradation for $0.5 \mathrm{~h}$ and mannose concentration increased with prolonging the hydrolysis time. The result confirmed that Tth Man $5 \beta$-mannosidase only displayed exo-enzyme activity.

\section{Phylogenetic analysis of Tth Man5 $\beta$-mannosidase}

The phylogenetic trees generated from 35 candidate sequences were constructed to gain deeper insight into the evolutionary relationship among $\beta$-mannosidases, using the Neighbor-Joining (NJ) and Maximum-Parsimony (MP) methods. Both trees displayed almost the same topological structures (NJ tree was not shown). It revealed the presence of three well-supported clades and each clade consisting of a separated monophyletic group (Figure 6). Clade I, Clade II and Clade III consisted of the GHF2, GHF5 and GHF1 $\beta$-mannosidases, respectively. From the phylogenetic trees, it is obvious that there are two subclades in Clade II. Tth Man5 $\beta$ mannosidase from $T$. thermarum showed an apparently distant relationship with the GHF5 $\beta$-mannosidases from the same genus. Therefore, it was presumed that the biochemical properties of Tth Man $5 \beta$-mannosidase might differ from the same genus $\beta$-mannosidases. This was confirmed by the experiment results shown in Table 4 .

\section{Discussion}

$\beta$-Mannosidase is an important hydrolytic enzyme which attacks the non-reducing end of the $\beta$-linked

Table 2 Specific activity of Tth Man5 $\beta$-mannosidase on various substrates

\begin{tabular}{|c|c|}
\hline Substrate & $\begin{array}{l}\text { Specific activity } \\
\left(\mu \mathrm{mol} \mathrm{min}^{-1} \mathrm{mg}^{-1}\right)\end{array}$ \\
\hline$p$-nitrophenyl- $\beta$-D-mannopyranoside & $102.00 \pm 2.65$ \\
\hline 1,4- $\beta$-D-mannan & $89.50 \pm 1.34$ \\
\hline galactan & ND \\
\hline konjaku powder & ND \\
\hline guar galactomannan & ND \\
\hline
\end{tabular}

ND: not detected. Values shown were the mean of triplicate experiments, and the variation about the mean was below $5 \%$. 
Table 3 Effects of cations and chemical reagents on purified Tth Man5 $\beta$-mannosidase activity

\begin{tabular}{ll}
\hline Cations $^{\mathbf{a}}$ & Residual activity (\%) \\
\hline Control & 100 \\
$\mathrm{Mg}^{2+}$ & $114.85 \pm 5.50$ \\
$\mathrm{Zn}^{2+}$ & $25.63 \pm 2.20$ \\
$\mathrm{Mn}^{2+}$ & $129.61 \pm 2.88$ \\
$\mathrm{Ba}^{2+}$ & $107.96 \pm 3.84$ \\
$\mathrm{Ca}^{2+}$ & $103.01 \pm 2.33$ \\
$\mathrm{Al}^{3+}$ & $109.61 \pm 3.50$ \\
$\mathrm{Cu}^{2+}$ & $28.93 \pm 1.22$ \\
$\mathrm{Co}^{2+}$ & $191.94 \pm 7.27$ \\
$\mathrm{Ni}^{2+}$ & $81.07 \pm 0.69$ \\
$\mathrm{Chemical}^{2+}$ & \\
EDTA & \\
Tween 60 & $119.32 \pm 1.24$ \\
Tris & $100.19 \pm 3.76$ \\
SDS & $58.34 \pm 0.96$ \\
\hline
\end{tabular}

${ }^{a}$ Final concentration, the former value in the table was determined at $1 \mathrm{mM}$. ${ }^{\mathrm{b}}$ Final concentration, the values in the table were determined at $1 \mathrm{mM}, 0.05 \%$, $0.05 \%$ and $0.1 \%$ for EDTA, Tween 60 , Tris and SDS, respectively. Values shown were the means of triplicate experiments.

mannooligosaccharides to release mannoses [17]. It plays a key role in the degradation pathway of complex oligosaccharide and glycoproteins [5]. To our knowledge, the hydrolytic end product by $\beta$-mannosidase, mannoses, are also fermentable sugars which can be bio-converted to bio-fuels and value-added chemicals [18]. The release of the genome in database provides us an effective way to investigate the uncharacterized enzymes, which may have great potential in industrial applications. For this study, a putative endo- $\beta$-mannanase gene (Theth_0949) from $T$. thermarum was cloned and was finally defined as a $\beta$-mannosidase through the biochemical characterization.
The T. thermarum $\beta$-mannosidase is distinct from the other glycosyl hydrolases from T. thermarum. The substrate specificity and amino acid sequence of the $\beta$-mannosidase are apparently different from those of the xylanase and $\beta$-xylosidase from $T$. thermarum previously reported $[19,20]$. Based on sequences similarity, the Tth Man5 $\beta$-mannosidase belongs to GHF5. It has a homologous relationship with those from $S$. cellulosum (33\%), A. mirum (32\%) and S. flavogriseus (32\%) (Figure 1). Compared to the same genus Thermotoga $\beta$-mannosidase from GHF5 or GHF2, however, there is great difference according to phylogenetic analysis and they belong to different monophyletic groups (Figure 6). This suggests that Tth Man $5 \beta$-mannosidase may have some specific properties. Like other hemicellulases, the catalytic mechanism of $\beta$-mannosidase is also a double displacement lysozymelike reaction, involving stabilization of an oxocarbonium ion by electrostatic interaction with two glutamate acid residues at the active site [2]. By the alignment with other GHF5 $\beta$-mannosidases and a GHF5 cellulase from Pseudoalteromonas haloplanktis (EXPDB No. 1TVP:A), the acid/base and the nucleophile are identified as Glu141 and Glu238 residues, respectively [16]. It is difficult to know more details about the functional amino acid residues as lack of a suitable template for homology modeling. Therefore, a crystalline structure analysis is needed to further investigate.

The Tth Man5 $\beta$-mannosidase from T. thermarum DSM 5069 exhibits the highest activity at temperature $85^{\circ} \mathrm{C}$ (Figure 3c). The temperature optima is higher than the $\beta$-mannosidases from Homo sapiens, Aplysia kurodai, Bacillus licheniformis, Bacillus circulans, Aspergillus niger and Aspergillus awamori, in which optimal temperature are ranged from $37^{\circ} \mathrm{C}$ to $70^{\circ} \mathrm{C}$ [3-5,17,21]. It is found that the $\beta$-mannosidases from the genus Thermotoga and Pyrococcus furiosus exhibit the maximum activity above $80^{\circ} \mathrm{C}$ [11-13]. However, $\mathrm{pH}$ optima for animals and fungi are near 5.0 while for bacteria occurs at neutral

Table 4 Characteristics of $\beta$-mannosidases from different sources for ${ }^{a} p N P M$ as substrate

\begin{tabular}{|c|c|c|c|c|c|c|c|}
\hline Strain & $\begin{array}{l}V_{\max } \\
\left(\mu \mathrm{mol} \min ^{-1} \mathrm{mg}^{-1}\right)\end{array}$ & $K_{m}(\mathrm{mM})$ & $k_{\text {cat }}\left(\mathrm{s}^{-1}\right)$ & $\begin{array}{l}k_{\text {cat }} / K_{m} \\
\left(\mathrm{mM}^{-1} \mathrm{~s}^{-1}\right)\end{array}$ & $\begin{array}{l}K_{i} \text { for mannose } \\
(\mathrm{mM})\end{array}$ & $\begin{array}{l}\text { Optimal } \\
\text { Temp }\left({ }^{\circ} \mathrm{C}\right)\end{array}$ & Reference \\
\hline Thermotoga thermarum & $227.27 \pm 1.59$ & $4.36 \pm 0.05$ & $1924.29 \pm 13.47$ & $441.35 \pm 0.04$ & 900 & 85 & This work \\
\hline Thermotoga neapolitana & $36.9 \pm 2.5$ & $3.1 \pm 2.5$ & ${ }^{c} 67.83$ & ${ }^{c} 24.23$ & ${ }^{b} \mathrm{ND}$ & 90 & 11 \\
\hline Thermotoga maritima & 50.5 & 0.49 & ${ }^{c} 8.43$ & ${ }^{c} 17.22$ & ND & 95 & 10 \\
\hline Pyrococcus furiosus & 31.1 & 0.79 & 31.1 & 40 & ND & 105 & 12 \\
\hline Thermoascus aurantiacus & $c_{3.66}$ & 1.1 & 6.1 & 5.5 & ND & 76 & 17 \\
\hline Aspergillus niger & $c_{30}$ & 0.3 & ${ }^{c} 67.5$ & ${ }^{c} 225$ & ND & 70 & 16 \\
\hline Thermobifida fusca & 5.96 & 0.18 & ${ }^{c} 9.34$ & ${ }^{c} 51.89$ & 5.5 & 53 & 22 \\
\hline Aplysia kurodai & 3.75 & 0.1 & ${ }^{c} 6.25$ & ${ }^{c} 62.5$ & ND & 40 & 3 \\
\hline
\end{tabular}

${ }^{a} p$ NPM: $p$-nitrophenyl- $\beta$-D-mannopyranoside.

${ }^{\mathrm{b}} \mathrm{ND}$ : not determined.

${ }^{c}$ Calculated by the data based on the reference. 

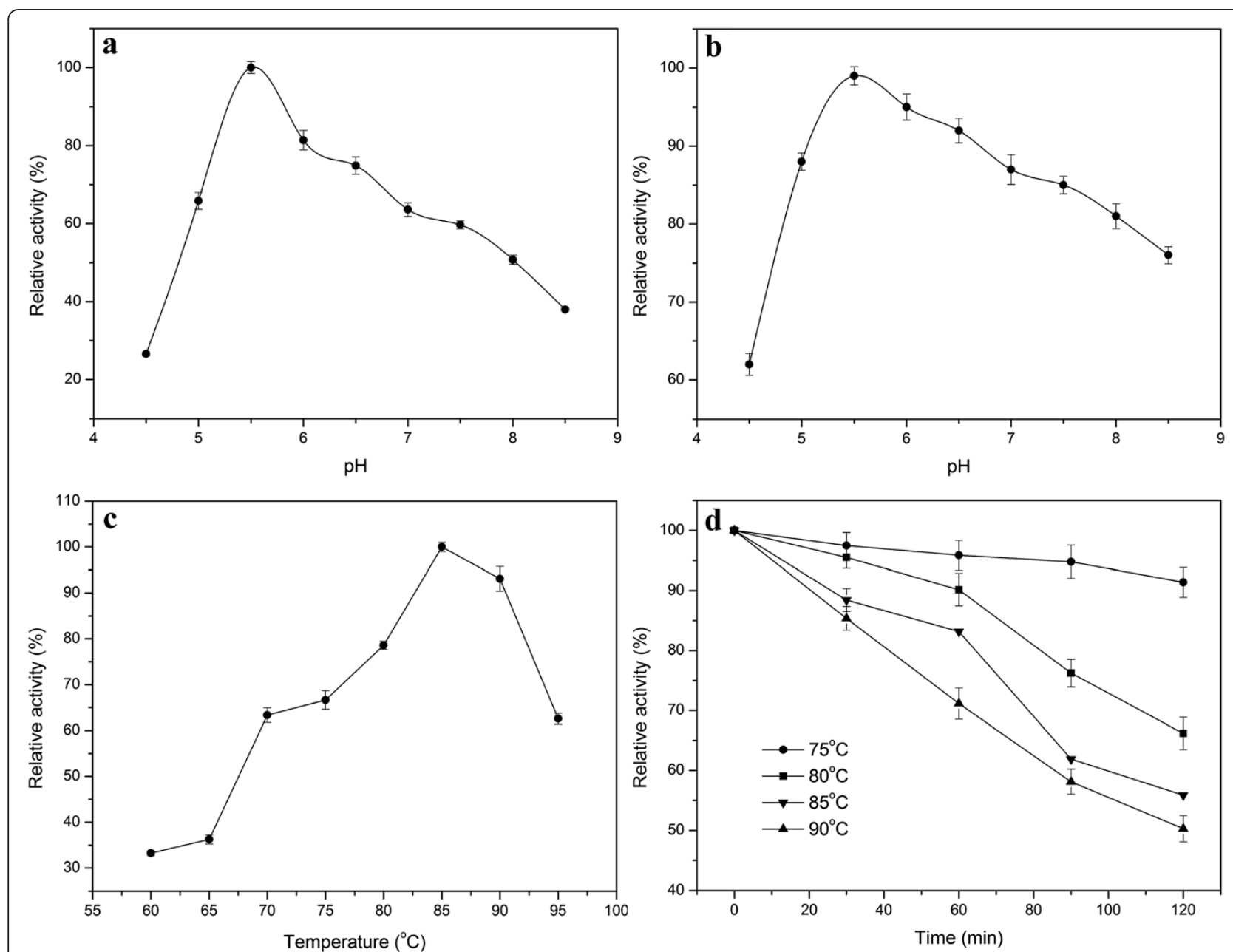

Figure 3 Effects of $\mathrm{pH}$ and temperature on the activity and stability of the recombinant Tth Man5 $\beta$-mannosidase. a. Optimal pH of the Tth Man5 $\beta$-mannosidase. b. pH stability of the Tth Man5 $\beta$-mannosidase. c. Effect of temperature on Tth Man5 $\beta$-mannosidase activity. d. The thermostability of the Tth Man5 $\beta$-mannosidase. The residual activity was monitored, and the maximum activity was defined as $100 \%$ (a, c) or initial activity was defined as $100 \%$ (b, d). Values shown were the mean of triplicate experiments, and the variation about the mean was below $5 \%$.

environment. As we know, the enzymes with high thermal stability are necessary in industrial progresses and thus it can minimize the enzyme consumption and enhance the catalytic efficiency. The Tth Man5 $\beta$-mannosidase residual activity retains approximately $91 \%$ after being incubated at $75^{\circ} \mathrm{C}$ for $2 \mathrm{~h}$. Furthermore, the Tth Man $5 \beta$-mannosidase residual activity is still more than $50 \%$ even after being incubated at $90^{\circ} \mathrm{C}$ for $2 \mathrm{~h}$. It shares similar thermostability at high temperature with the $\beta$-mannosidases from hyperthermophile. For instance, T. neapolitana $\beta$-mannosidase was stable at $90^{\circ} \mathrm{C}$ for $2 \mathrm{~h}$ and T. maritima $\beta$-mannosidase was stable at $80^{\circ} \mathrm{C}$ for $4 \mathrm{~h}[11,13]$. The activity of $\beta$ mannosidase is significantly inhibited by $\mathrm{Cu}^{2+}$ and $\mathrm{Zn}^{2+}$ and this is similar to the $\beta$-mannosidase from Homo sapiens whose activity is thoroughly decreased the activity by the addition of $1.5 \mathrm{mM} \mathrm{Cu}^{2+}$ or $\mathrm{Zn}^{2+}$. However, the enzyme activity is greatly stimulated by $\mathrm{Co}^{2+}$ and $\mathrm{Mn}^{2+}$
(Table 3), very different from Thermotoga maritima $\beta$ mannosidase which enzyme activity is apparently inhibited by the both ions [11].

$\beta$-Mannosidase is known to be a key enzyme for converting mannooligosaccharides to mannoses, the end products, which are able to inhibit the enzymatic reaction to a certain extent. Therefore, $\beta$-mannosidases with high tolerance to mannoses are beneficial to conversion of mannooligosaccharides. However, little information about mannose-tolerant $\beta$-mannosidase is available in literatures. As shown in Figure 4, Tth Man5 $\beta$-mannosidase is insensitive to mannose (48.0\% of inhibition at $900 \mathrm{mM}$ ) whereas the $K_{i}$ for Thermobifida fusca $\beta$-mannosidase is only $5.5 \mathrm{mM}[10]$, suggesting a high tolerance to mannose inhibition. Moreover, high enzyme activity is also demanded for $\beta$-mannosidase in enzymatic hydrolysis of mannooligosaccharides. The $V_{\max }$ value of Tth Man5 


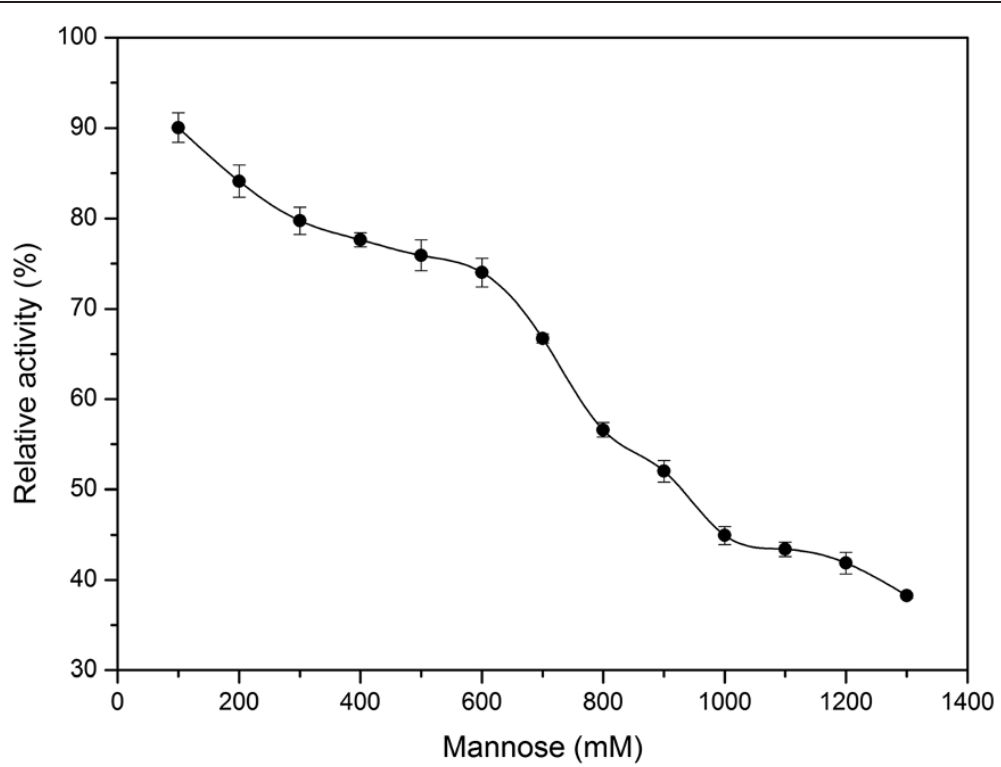

Figure 4 Effect of mannose on Tth Man5 $\beta$-mannosidase activity using $p$-nitrophenyl- $\beta$-D-mannopyranoside as the substrate. Values shown were the mean of three separate experiments, and the variations about the mean were all below $5 \%$.

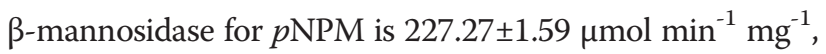
7 -fold higher than thermostable $\beta$-mannosidases from $T$. neapolitana and P. furiosus, 38-fold higher than T. fusca $\beta$-mannosidase and 62-fold than Thermoascus aurantiacus $\beta$-mannosidase $[10,12,13,18]$. The $k_{\text {cat }} / K_{m}$ of Tth Man5

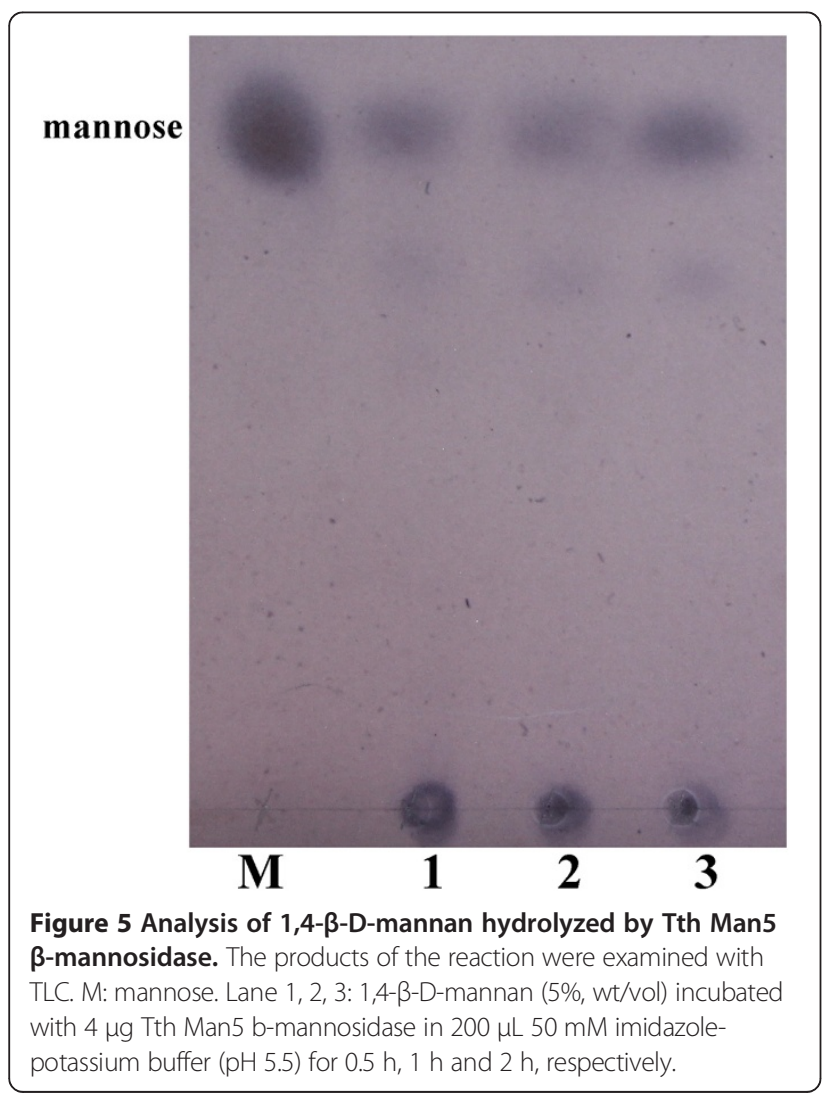

$\beta$-mannosidase for $p N P M$ is $441.35 \pm 0.04 \mathrm{mM}^{-1} \mathrm{~s}^{-1}$, approximately 2 -fold higher than $A$. niger $\beta$-mannosidase, 11 -fold higher than the $P$. furiosus $\beta$-mannosidase, 18fold higher than the $T$. neapolitana $\beta$-mannosidase and 80-fold higher than the Thermoascus aurantiacus $\beta$ mannosidase [12,13,17,18]. Generallly, it is noteworthy that Tth Man5 $\beta$-mannosidase has the highest $V_{\max }$ and $k_{\text {cat }} / K_{m}$ value (Table 4 ). Therefore, its mannose tolerance and high catalytic efficiency are desirable features for potential industrial applications.

Due to its theoretical and practical importance we investigated the hydrolysis of different substrates. When 1,4- $\beta$ D-mannan was degraded by Tth Man5 $\beta$-mannosidase, mannose was produced as a major product (Figure 5 ). It states that Tth Man5 $\beta$-mannosidase is a typical $\beta$ mannosidase and acts on polymer substrate with an exolytic manner. Such an exo-type action has been found in the $\beta$-mannosidase from a marine gastropod, Aplysia kurodai [3]. It is obvious that Tth Man5 $\beta$-mannosidase has a significant ability for the hydrolysis of $1,4-\beta-D-$ mannan (linear mannan by removing essentially all of the $\alpha$-linked D-galactosyl residues from galactomannan with $\beta$-mannanase and $\alpha$-galactosidase) with the $V_{\max }$ of $285.71 \pm 10.86 \mu \mathrm{mol} \mathrm{min}{ }^{-1} \mathrm{mg}^{-1}$. However, no activity is detected on konjaku powder and guar galactomannan which are not pretreated with any enzymes. The results indicate that Tth Man5 $\beta$-mannosidase can act on galactomannan cooperatively with $\beta$-mannanase and $\alpha$ galactosidase to produce mannose efficiently but can not act with only Tth Man $\beta$-mannosidase. As Tth Man $\beta$ mannosidase can degrade 1,4- $\beta$-D-mannan with high efficiency, it is deduced that it also can efficiently 


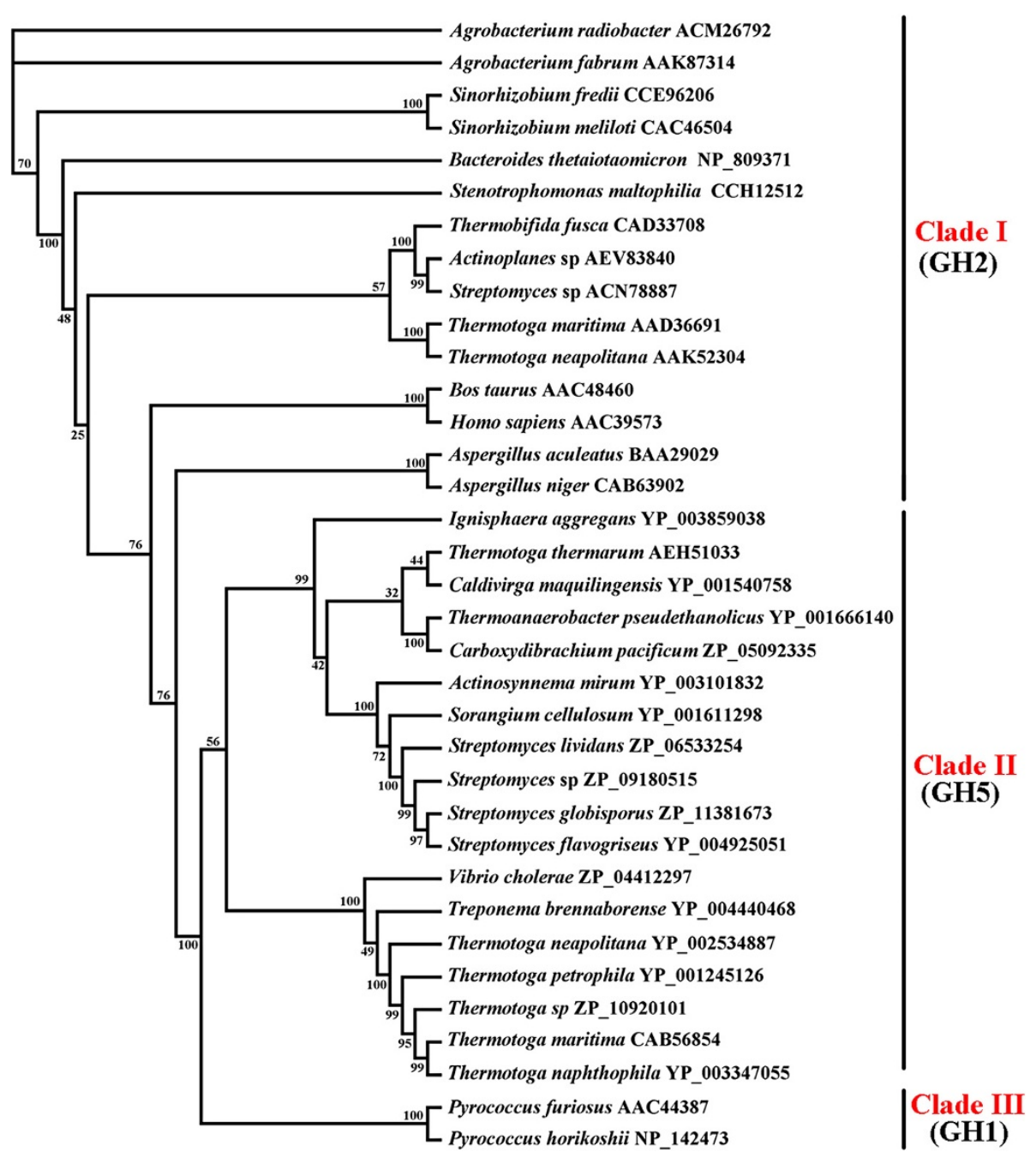

Figure 6 Phylogentic tree resulted from analysis of $\beta$-mannosidases with 35 amino acid sequences using Maximum-Parsimony (MP) method. Numbers on nodes correspond to percentage bootstrap values for 1000 replicates.

hydrolyze mannooligosaccharides whose degree of polymerization is less than 1,4- $\beta$-D-mannan.

\section{Conclusions}

In this study, a novel $\beta$-mannosidase (Tth Man5) from T. thermarum DSM 5069 was over-expressed in E. coli with some specific features. The results of phylogenetic analysis and biochemical properties showed that the Tth Man5 $\beta$-mannosidase was distant with the other genus Thermotoga $\beta$-mannosidases. As compared to other microorganisms, the Tth Man5 $\beta$-mannosidase possessed higher tolerance to mannose, higher catalytic efficiency and higher thermostability. Therefore, this study provides a novel and useful $\beta$-mannosidase with combined properties of high catalytic efficiency, mannose-tolerance and thermostability. This is easily envisioned that Tth
Man5 $\beta$-mannosidase exhibits a great potential for enzymatic conversion of mannans.

\section{Methods}

Bacterial strains and growth conditions

Thermotoga thermarum DSM5069 was purchased from DSMZ; German Culture Collection of Microorganisms and Cell Cultures (Braunschweig, Germany). Escherichia coli Top10 (Novagen) was used for routine molecular cloning work and E. coli BL21 (DE3) (Novagen) as the host for expression the recombinant $\beta$-mannosidase. The vectors pET-20b and pET-28a were used for cloning and expression. Cells of recombinant strain (E. coli Top10 or E. coli BL21 (DE3)) harboring pET-20b-Tth man5 and pET-28a-Tth man5 were grown in Luria-Bertani (LB) medium with addition of ampicillin $\left(100 \mu \mathrm{g} \mathrm{ml}^{-1}\right)$ and 
kanamycin $\left(50 \mu \mathrm{g} \mathrm{ml}^{-1}\right)$, respectively. Isopropyl- $\beta$-D-thiogalactopyranoside (IPTG) was added with the concentration of $0.5 \mathrm{mM}$.

\section{Construction of plasmids and strains}

DNA extraction was carried out as standard methods [22]. Restriction enzymes and DNA polymerase were purchased from Takara (Dalian, China) and used according to the manufacturer's instructions. DNA was eluted from agarose gels with BIOMIGA Gel Extraction Kit (BIOMIGA, Shanghai). DNA sequencing was performed with ABI 3730 (Applied Biosystems). PCR amplifications were done using high-fidelity Ex-Taq DNA polymerase, and the resulting products purified by BIOMIGA PCR Purification Kit (BIOMIGA, Shanghai).

The coding sequence of Tth man 5 gene was amplified by PCR of genomic DNA using primer 1 and primer 2 as shown in Table 1. The synthesized codon optimized gene fragment was amplified using primer 3 and primer 4 as shown in Table 5 . The primers 1 and 2 introduced the restrictions sites $\mathrm{NcoI}$ and $\mathrm{XhoI}$ at the 5' and 3' end, respectively. Primers 3 and 4 used NdeI and XhoI restrictions sites. PCR was performed as follows: $94^{\circ} \mathrm{C}, 5$ min; 30 cycles of $94^{\circ} \mathrm{C}$ for $30 \mathrm{~s}, 55^{\circ} \mathrm{C}$ for $30 \mathrm{~s}$ and $72^{\circ}$ $\mathrm{C}$ for $100 \mathrm{~s}$; and $72^{\circ} \mathrm{C}, 10 \mathrm{~min}$. The amplified DNA fragments were digested with the corresponding restriction endonucleases, and inserted into the corresponding sites in pET-28a and pET-20b (Novagen) to produce recombinant plasmids. The two plasmids encode a recombinant $\beta$ mannosidase bearing a C-terminal $\mathrm{His}_{6}$-tag, under the control of a T7 inducible promoter. The sequence of the inserts in pET-28a and pET-20b was confirmed by DNA sequencing.

\section{Expression and purification of recombinant $\beta$-mannosidase}

E. coli BL21 (DE3) cells in $200 \mathrm{~mL}$ of LB with appropriate antibiotic selection harbouring recombinant plasmids were grown at $37^{\circ} \mathrm{C}$ and $200 \mathrm{rpm}$. When the $\mathrm{OD}_{600}$ reached 0.4 to 0.5 , the expression of $\beta$-mannosidase was induced by the addition of $0.5 \mathrm{mM}$ IPTG and the culture was incubated at $37^{\circ} \mathrm{C}$ and $200 \mathrm{rpm}$ for $5 \mathrm{~h}$. Cells were harvested by centrifugation at $4^{\circ} \mathrm{C}(10000 \mathrm{rpm}, 5 \mathrm{~min})$, washed twice with $20 \mathrm{mM}$ Tris- $\mathrm{HCl}$ buffer $(\mathrm{pH} 8.0)$, and re-suspended in $5 \mathrm{~mL}$ of $5 \mathrm{mM}$ imidazole, $0.5 \mathrm{mM}$ $\mathrm{NaCl}$, and $20 \mathrm{mM}$ Tris- $\mathrm{HCl}$ buffer ( $\mathrm{pH}$ 7.9). The cell extracts after sonication were heat treated at $70^{\circ} \mathrm{C}$ for $30 \mathrm{~min}$, cooled in an ice bath, and then centrifuged $\left(15000 \mathrm{~g}, 4^{\circ} \mathrm{C}, 20 \mathrm{~min}\right)$. The obtained supernatants were loaded on to an immobilized metal affinity column $(2 \mathrm{~mL})$ (Novagen, USA) with a flow rate $0.2 \mathrm{~mL} \mathrm{~min}^{-1}$. Finally, 1 $\mathrm{mL}$ fractions were collected by eluting with $0.4 \mathrm{M}$ imidazole, $0.5 \mathrm{M} \mathrm{NaCl}$, and $20 \mathrm{mM}$ Tris- $\mathrm{HCl}$ buffer ( $\mathrm{pH} 7.9$ ). The fractions containing $\beta$-mannosidases were dialyzed
Table 5 Nucleotide sequences of the primers used

\begin{tabular}{|c|c|}
\hline Primer & Nucleotide sequence \\
\hline 1 & $\begin{array}{l}\text { 5'-CATGCCATGGGCATGGATTTTCTTCTTGGCATCAATT-3', } \\
\mathrm{Tm}=62.7^{\circ} \mathrm{C}\end{array}$ \\
\hline 2 & $\begin{array}{l}\text { 5'-CCGCTCGAGAAAGTTCAGCAATTTGTACTCTTTG-3', } \\
\mathrm{Tm}=57.6^{\circ} \mathrm{C}\end{array}$ \\
\hline 3 & $\begin{array}{l}\text { 5'-GGAATTCCATATGGATTTCCTGCTGGGTATTAACTACT-3', } \\
\mathrm{Tm}=62.0\end{array}$ \\
\hline 4 & $\begin{array}{l}\text { 5'-CCGCTCGAGGAAGTTCAGCAGCTTATACTCTTTC-3', } \\
\mathrm{Tm}=56.7\end{array}$ \\
\hline
\end{tabular}

overnight against storage buffer $(20 \mathrm{mM}$ Na-phosphate buffer, pH7.0, $50 \mathrm{mM} \mathrm{NaCl}, 10 \%$ glycerol) and then kept at $-80^{\circ} \mathrm{C}$ until further use. The analysis of production, purity and molecular mass of the enzymes were determined by SDS-PAGE, using broad range molecular weight markers purchased from Thermo Fisher Scientific Inc. (12-94 kDa, MBI Fermemtas) as standards. The protein content was determined using Bradford reagent with albumin from bovine serum as standard. Oligomerization state of Tth Man $\beta$-mannosidase was determined by size exclusion chromatography on a AKTAFPLC ${ }^{\mathrm{m}}$ (GE Healthcare Life Sciences) system with a Superdex 200 10/30 GL column as described by Zhang et al. [23].

\section{Enzyme assays}

Substrate $p$ NPM (Sigma, USA) was used for $\beta$ mannosidase activity analysis. Under standard assay condition, the purified enzyme $(0.1 \mu \mathrm{g})$ was incubated with $10 \mu \mathrm{L}$ of $20 \mathrm{mM}$ substrate $p \mathrm{NPM}$ in $50 \mathrm{mM}$ imidazole-potassium buffer (pH 5.5) for $10 \mathrm{~min}$ at $85^{\circ} \mathrm{C}$. The total reaction volume was $0.2 \mathrm{~mL}$. Subsequently, $600 \mu \mathrm{l}$ of $1 \mathrm{M} \mathrm{Na}_{2} \mathrm{CO}_{3}$ was added to stop the reaction. The $p$-nitrophenol absorbance $(p \mathrm{NP})$ was measured at $405 \mathrm{~nm}$. One unit of enzyme activity was defined as the amount of enzyme necessary to liberate $1 \mu \mathrm{mol} p \mathrm{NP}$ per min under the assay conditions. All assays were performed in triplicate.

\section{Effect of temperature and $\mathrm{pH}$ on enzyme activity}

The optimum $\mathrm{pH}$ for $\beta$-mannosidase was determined by incubation at various $\mathrm{pH}$ conditions $(\mathrm{pH} 4.5-8.5)$ at $85^{\circ} \mathrm{C}$ for $10 \mathrm{~min}$ in $50 \mathrm{mM}$ imidazole-potassium buffer. The optimum temperature for the enzyme activity was determined by standard assay ranging from $60^{\circ} \mathrm{C}$ to $90^{\circ} \mathrm{C}$ in $50 \mathrm{mM}$ imidazole-potassium buffer at $\mathrm{pH}$ 5.5. The results were expressed as relative activity to the value obtained at either optimum temperature or optimum $\mathrm{pH}$. The maximum activity detected for $\mathrm{pH}$ optimum and temperature optimum were defined as $100 \%$. $\mathrm{PH}$ stability assays were determined by measuring residual $\beta$-mannosidase activity after pre-incubation of enzymes in the $\mathrm{pH}$ rang of 4.5 to 8.5 . Thermostability assays were determined by measuring residual $\beta$-mannosidase 
activity after pre-incubation of enzymes at $75^{\circ} \mathrm{C}, 80^{\circ} \mathrm{C}$, $85^{\circ} \mathrm{C}$, and $90^{\circ} \mathrm{C}$ for $30 \mathrm{~min}, 60 \mathrm{~min}, 90 \mathrm{~min}$ and $120 \mathrm{~min}$. The activity of the enzyme without pre-incubation was defined as $100 \%$.

\section{Effect of cations and chemical reagents}

The effects of metal ions and chemical reagents on $\beta$ mannosidase activity of purified enzyme $(0.1 \mu \mathrm{g})$ were determined. $\mathrm{Mg}^{2+}, \mathrm{Zn}^{2+}, \mathrm{Mn}^{2+}, \mathrm{Ca}^{2+}, \mathrm{Al}^{3+}, \mathrm{Ni}^{2+}, \mathrm{Cu}^{2+}$ and $\mathrm{Co}^{2+}$ were assayed at concentrations of $1 \mathrm{mM}$ in the reaction mixture. The chemical reagents EDTA $(1 \mathrm{mM})$, Tris $(0.05 \%)$, Tween $60(0.05 \%)$, and SDS $(0.1 \%)$ in the $0.2 \mathrm{~mL}$ reaction mixture were assayed. The enzyme was incubated with each reagent for $1 \mathrm{~h}$ at $85^{\circ} \mathrm{C}$ before the addition of $p$ NPM to start the enzyme reaction. The activity of the enzyme without the chemical reagents or metal cations was defined as $100 \%$.

\section{Kinetic parameters and coefficient of mannose tolerance} Kinetic constant of $\beta$-mannosidase was determined by measuring the initial rates at various concentrations of $p$ NPM ( 1 to $50 \mathrm{mM}$ ) under standard reaction conditions described as above. The influence of various mannose concentrations range from $0.1 \mathrm{M}$ to $1.3 \mathrm{M}$ on the $\beta$ mannosidase activity was investigated using $p$ NPM as substrate. The $K_{i}$ value of mannose was determined defined as amount of mannose required for inhibiting 50\% of the $\beta$-mannosidase activity. All assays were performed in triplicate.

\section{Substrate specificity}

The substrate specificity of the enzyme was determined by using following substrates, such as konjaku powder (Anhui, China), guar galactomannan (medium viscosity), 1,4- $\beta$-D-mannan and galactan (Megazyme International Ireland). The enzyme activities were assayed using the dinitrosalicylic acid (DNS) method [24]. The reaction mixture, containing $0.5 \%$ each substrate above and 0.1 $\mu \mathrm{g}$ enzyme in $0.2 \mathrm{~mL} 50 \mathrm{mM}$ imidazole-potassium buffer $(\mathrm{pH}$ 5.5) reaction system, were incubated for $10 \mathrm{~min}$ at $85^{\circ} \mathrm{C}$. The reaction was stopped by the addition of $0.3 \mathrm{~mL}$ DNS, followed by boiling for 5 minutes. The absorbance of the mixture was measured at $550 \mathrm{~nm}$ and converted to micromole of mannose by a mannose standard curve (data not shown). One unit of $\beta$-mannosidase activity was defined as the amount of enzyme releasing per $\mu \mathrm{mol}$ mannose per minute. Kinetic constant of $\beta$-mannosidase with each substrate was determined by measuring the initial rates at various concentrations from $1 \mathrm{mg} \mathrm{mL}^{-1}$ to $60 \mathrm{mg} \mathrm{mL}^{-1}$ under standard reaction conditions described as above. All assays were performed in triplicate.

\section{1,4- $\beta$-D-mannan degradation}

The 1,4- $\beta$-D-mannan was treated with purified Tth Man5 $\beta$-mannosidase, and the degradation was subjected to analysis on thin-layer chromatography (TLC). The reaction mixture $(200 \mu \mathrm{L})$ contained 5\% 1,4- $\beta$-D-mannan $(w \mathrm{wt} / \mathrm{vol})$ and $4 \mu \mathrm{g}$ of enzyme in $50 \mathrm{mM}$ imidazole-potassium buffer $(\mathrm{pH}$ 5.5). The reaction was carried out for various times $(0.5 \mathrm{~h}, 1 \mathrm{~h}$ and $2 \mathrm{~h})$ at $80^{\circ} \mathrm{C}$, and stopped in a water bath $\left(4^{\circ} \mathrm{C}\right)$. After centrifuged for $10 \mathrm{~min}$ at $12,000 \mathrm{rpm}$, the supernatants of the reaction mixtures were applied on silica gel TLC plates (G, Qingdao). Sugars on the plates were separated with a solvent system consisting of $n$-butanol, acetic acid, and water (2:1:1, by $\mathrm{vol} / \mathrm{vol})$, and detected using the orcinol/concentrated sulfuric acid reagent [25].

\section{Bioinformatics analysis}

A BLAST engine was used to search the amino acid sequences related to the $\beta$-mannosidase from $T$. thermarum and against the CAZy database. Clstal X2 was used for multiple sequence alignment [26]. Phylogenetic analysis was performed in Paup with the Neighbor-Joining (NJ) and Maximum-Parsimony (MP) methods [27].

\section{Amino acid sequence accession number}

The GenBank accession number of $\beta$-mannosidase from T. thermarum DSM 5069 is AEH51033.

\section{Competing interests}

The authors declare that they have no competing interests.

\section{Authors' contributions}

HS carried out the cloning, expression and drafted the manuscript. YH and YZ helped to purified and characterized the Tth Man5 $\beta$-mannosidase. WL and $X \mathrm{~L}$ helped to analyze the data. FW directed the over-all study and revised the manuscript. All authors read and approved the final manuscript.

\section{Acknowledgements}

This work was financially supported by the National Industry Special Project of China (No. 201004001), the National Natural Science Foundation of China (No. 31170537, 31370572), Jiangsu Provincial Government (CXZZ11_0526), the Doctorate Fellowship Foundation of Nanjing Forestry University, as well as the Priority Academic Program Development of Jiangsu Higher Education Institutions (PAPD)

Received: 9 July 2013 Accepted: 4 October 2013

Published: 8 October 2013

\section{References}

1. Petkowicz CLD, Reicher F, Chanzy H, Taravel FR, Vuong R: Linear mannan in the endosperm of Schizolobium amazonicum. Carbohydr Polym 2001, 44:107-112.

2. Moreira LRS, Filho EXF: An overview of mannan structure and mannandegrading enzyme systems. Appl Microbiol Biotechnol 2008, 79:165-178.

3. Zahura UA, Rahman MM, Inoue A, Ojima T: Characterization of a b-Dmannosidase from a marine gastropod, Aplysia kurodai. Comp Biochem Physiol B Biochem Mol Biol 2012, 162:24-33.

4. Songsiriritthigul C, Buranabanyat B, Haltrich D, Yamabhai M: Efficient recombinant expression and secretion of a thermostable GH26 mannan endo-1,4- $\beta$-mannosidase from Bacillus licheniformis in Escherichia coli. Microb Cell Fact 2010, 9:20.

5. Samra $Z Q$, Athar $M A$ : Cloning, sequence, expression and characterization of human beta-mannosidase. Acta Biochim Pol 2008, 55:479-490. 
6. Yang P, Li Y, Wang Y, Meng K, Luo H, Yuan T, Bai Y, Zhan Z, Yao B: A novel b-mannanase with high dpecific sctivity from Bacillus circulans CGMCC1554: Gene cloning, expression and enzymatic characterization. Appl Biochem Biotechnol 2008, 159:85-94.

7. Riise Stensland HMF, Persichetti E, Sorriso C, Hansen GM, Bibi L, Paciotti S, Balducci C, Beccari T: Identification of two novel b-mannosidosis -associated sequence variants: Biochemical analysis of b-mannosidase (MANBA) missense mutations. Mol Genet Metab 2008, 94:476-480.

8. Sabourdy F, Labauge P, Stensland H, Nieto M, Garcés V, Renard D, Castelnovo G, de Champfleur N, Levade T: A MANBA mutation resulting in residual beta-mannosidase activity associated with severe leukoencephalopathy: a possible pseudodeficiency variant. BMC Med Genet 2009, 10:84.

9. Turner P, Mamo G, Karlsson E: Potential and utilization of thermophiles and thermostable enzymes in biorefining. Microb Cell Fact 2007, 6:9.

10. Beki E, Nagy I, Vanderleyden J, Jager S, Kiss L, Fulop L, Hornok L, Kukolya J: Cloning and heterologous expression of a b-D-mannosidase (EC 3.2.1.25)-encoding gene from Thermobifida fusca TM51. App/ Environ Microbiol 2003, 69:1944-1952

11. Zhang M, Jiang Z, Li L, Katrolia P: Biochemical characterization of a recombinant thermostable $\beta$-mannosidase from Thermotoga maritima with transglycosidase activity. J Mol Catal B Enzym 2009, 60:119-124.

12. Bauer MW, Bylina EJ, Swanson RV, Kelly RM: Comparison of a betaglucosidase and a beta-mannosidase from the hyperthermophilic archaeon Pyrococcus furiosus. Purification, characterization, gene cloning, and sequence analysis. The Journal of biological chemistry 1996, 271:23749-23755.

13. Duffaud GD, McCutchen CM, Leduc P, Parker KN, Kelly RM: Purification and characterization of extremely thermostable beta-mannanase, betamannosidase, and alpha-galactosidase from the hyperthermophilic eubacterium Thermotoga neapolitana 5068. Appl Environ Microbiol 1997, 63:169-177.

14. Windberger $\mathrm{E}$, Huber $\mathrm{R}$, Trincone A, Fricke H, Stetter KO: Thermotoga thermarum sp.nov and Thermotoga neapolitana ocurring in African continental solfataric springs. Arch Microbiol 1989, 151:506-512.

15. van Dijl JM, Hecker M: Bacillus subtilis: from soil bacterium to supersecreting cell factory. Microb Cell Fact 2013, 12:3.

16. Violot S, Aghajari N, Czjzek M, Feller G, Sonan GK, Gouet P, Gerday C, Haser $R$, Receveur-Bréchot V: Structure of a full Length psychrophilic cellulase from Pseudoalteromonas haloplanktis revealed by X-ray diffraction and small angle X-ray scattering. Journal of molecular biology 2005, 348:1211-1224.

17. Ademark P, Lundqvist J, Hagglund P, Tenkanen M, Torto N, Tjerneld F, Stalbrand $\mathrm{H}$ : Hydrolytic properties of a beta-mannosidase purified from Aspergillus niger. J Biotechnol 1999, 75:281-289.

18. Gomes J, Terler K, Kratzer R, Kainz E, Steiner W: Production of thermostable b-mannosidase by a strain of Thermoascus aurantiacus: Isolation, partial purification and characterization of the enzyme. Enzyme Microb Technol 2007, 40:969-975.

19. Shi H, Zhang Y, Li X, Huang Y, Wang L, Wang Y, Ding H, Wang F: A novel highly thermostable xylanase stimulated by $\mathrm{Ca}^{2+}$ from Thermotoga thermarum: cloning, expression and characterization. Biotechnology for Biofuels 2013, 6:26.

20. Shi H, Li X, Gu H, Zhang Y, Huang Y, Wang L, Wang F: Biochemical properties of a novel thermostable and highly xylose-tolerant betaxylosidase/alpha-arabinosidase from Thermotoga thermarum. Biotechnology for Biofuels 2013, 6:27

21. Kurakake M, Komaki T: Production of beta-mannanase and betamannosidase from Aspergillus awamori K4 and their properties. Curr Microbiol 2001, 42:377-380.

22. Mahuku GS: A simple extraction method suitable for PCR-based analysis of plant, fungal, and bacterial DNA. Plant Mol Biol Report 2004, 22:71-81.

23. Zhang Y, Raudah S, Teo H, Teo GWS, Fan R, Sun X, Orner BP: Alanineshaving mutagenesis to determine key interfacial residues governing the assembly of a nano-cage maxi-ferritin. J Biol Chem 2010, 285:12078-12086.

24. Miller GL: Use of dinitrosalicylic acid reagent for determination of ruducing sugar. Anal Chem 1959, 31:426-428

25. Okuyama M, Okuno A, Shimizu N, Mori H, Kimura A, Chiba S: Carboxyl group of residue Asp647 as possible proton donor in catalytic reaction of alpha-glucosidase from Schizosaccharomyces pombe. Eur J Biochem 2001, 268:2270-2280.

26. Larkin MA, Blackshields G, Brown NP, Chenna R, McGettigan PA, McWilliam H, Valentin F, Wallace IM, Wilm A, Lopez R, et al: Clustal W and clustal $X$ version 2.0. Bioinformatics 2007, 23:2947-2948.

27. Wilgenbusch JC, Swofford D: Inferring evolutionary trees with PAUP*. Curr Protoc Bioinformatics 2003. Chaper 6, unit 6.4. http://www.currentprotocols. com/protocol/bi0604.

doi:10.1186/1472-6750-13-83

Cite this article as: Shi et al.: High-level expression of a novel

thermostable and mannose-tolerant $\beta$-mannosidase from Thermotoga

thermarum DSM 5069 in Escherichia coli. BMC Biotechnology 2013 13:83.

\section{Submit your next manuscript to BioMed Central and take full advantage of:}

- Convenient online submission

- Thorough peer review

- No space constraints or color figure charges

- Immediate publication on acceptance

- Inclusion in PubMed, CAS, Scopus and Google Scholar

- Research which is freely available for redistribution 